\title{
Development of Jam from Under Exploited Fruit Aliv (Meyna laxiflora Robyns)
}

\author{
Pravin N. Dhodade ${ }^{1}$, Yogesh P. Dhaygude ${ }^{2}$, \\ Amit Kumar Tiwari ${ }^{3}$ and Vishal R. Birwatkar ${ }^{4}$ \\ College of Food Technology, Achloli, Mahad, Maharashtra, India \\ *Corresponding author:
}

\begin{abstract}
A B S T R A C T
Aliv fruit jam was developed in the present study. The finding of this study shows that the developed product of aliv jam has maximum consumer acceptance, due to its highly antioxidant activity and taste. A new formulated Alivfruit jam was prepared and biological, chemical and physical analysis was performed. The product were also tested for sensory properties and it was found good. The developed aliv fruit jam was packed in glass jar and stored at a temperature of $25 \pm 1.5^{\circ} \mathrm{C}$. A significant increase in $\mathrm{pH}$ was observed in aliv fruit jam during storage. A significant decrease in T.S.S. during storage of jam. No significant effect of packaging material was found on $\mathrm{pH}$ and T.S.S. of developed product. Based on the high overall acceptability scores and acceptable T.S.S. and pH. Aliv fruit jam developed and packed in glass jars was highly acceptable up to 3 month by consumer. Sensory evaluation of aliv jam was carried out sample $S_{3}$ observed highest score followed by $S_{2}$, and $S_{1}$. The sample scored higher for appearance followed by $S_{1} \& S_{2}$. The taste of sample significantly affected with addition of fresh aliv pulp.
\end{abstract}

Keywords

Antioxidants, Sensory analysis, Aliv fruit, Jam, Fruit products

Article Info

Accepted:

10 February 2019

Available Online:

10 March 2019

\section{Introduction}

Meyna laxiflora Robyns. Family Rubiaceae commonly known as manakkarai (Tamil), muyna, muduna (Hindi, Bengali) and gobergally (Kannada) is a spinescent or unarmed shrub or a small tree found in Western UP, West Bengal, North-east India and Deccan peninsula. Leaves are ovate to elliptic; flowers in lax cymes, greenish white; drupes are subglobose, green to brown. Seeds are albuminous with a membranous testa. Different parts of the plant were used in the treatment of boils, dysentery, diphtheria etc. Antioxidant activity of the Meynalaxiflora fruit pulp has already been reported. Free radicals are generated as part of the body's normal metabolic process and play a dual role in our body as both deleterious and beneficial species. Excess production of reactive oxygen species (ROS) and a decrease in antioxidant levels, this may leads tissue damage and causes different diseases. Antioxidant plays a major role to protect our body from disease by reducing the oxidative damage to cellular component caused by ROS. Recent 
investigations suggest that the plant origin antioxidants with free-radical scavenging properties may have great therapeutic importance in free radical mediated diseases like diabetes, cancer, neurodegenerative disease, cardiovascular diseases, aging, gastrointestinal diseases, arthritis and aging process. Many synthetic antioxidant compounds have shown toxic and mutagenic effects, relatively plant based medicine confer less side effect than the synthetic drug. Several investigations showed that seeds of various fruits are an important source of natural antioxidant. In view of the above observation our interest was to find out natural antioxidant from seeds of Meynalaxiflora using in vitro antioxidant activity. A scientific study of wild fruits is important for the potential sources which could be utilized at the time of scarcity or during normal days or cultivated as a source of food material for an ever increasing population. Fruits have satisfactory edible proteins with high quality so that we can use them in food industries and as nutrition. Fruits are generally high in fiber, water, vitamin $\mathrm{C}$ and sugars. From ancient time edible wild fruits played a very vital part in supplementing the diet of the people. The fruit contain Nitrogen (0.44 \pm 0.004$)$, Phosphorus (0.15 \pm 0.004), Calcium (325.10 \pm 0.066$)$, Potassium (1278.00 \pm 2.6$)$, Magnesium (99.5 \pm 0.90$)$, Iron (35.55 \pm 0.47$)$, Manganese (0.94 \pm 0.04$)$, Zinc (5.21 \pm 0.09$)$, Copper (0.84 \pm 0.03$)$, and Sodium $(221.00 \pm 1.70)$, Oxalate $(0.8667 \pm$ 0.1527), Phytate (0.2667 \pm 0.0577), Tannin(1.06 \pm 0.0529$)$, and Saponin (53.366 \pm $0.472) \mathrm{mg} / 100 \mathrm{gm}$. Fruits and vegetables are the fundamental and vital elements in the human diet. They make a significant nutritional contribution to human's diet due to their high nutritional value. They are the best source of vitamin A and C, considered as protective foods and are not much expensive. Fruits are not only consumed as fresh, but are also processed in the form of products. With the advances in food science and technology, processing and preservation have ensured maximum utilization of $\mathrm{C}$ and $\mathrm{D}$ grade fruits, including deformed, de-shaped, underdeveloped for the utilization and converting them into valuable food products. It is also very economical to preserve seasonal fruits to prepare different fruit products when they are in glut season and sold at throw away prices. Fruits can be processed in different ways. Their pulp can be preserved to prepare squash, jams, purees, etc. It has now become more important for food technologists not only to process the fruits and vegetable into valuable food products, but also to guide the consumers to select these food products according to new concepts of blood group to remain healthy and prevent diseases.

\section{Materials and Methods}

\section{Preparation of Aliv pulp}

The fresh aliv fruits were purchased from mahad, Maharashtra. The blanching of fruits was done to remove the physical and chemical contamination from fruits surface. The fruit was sliced in two part longitudinally to remove the seed and then it grind with some others ingredients to make jam.

\section{Physicochemical parameters of developed aliv jam}

The physicochemical parameters (T.S.S, pH, moisture and acidity) of product was measured for 90 days at interval of 30 days. $\mathrm{pH}$ was checked by using $\mathrm{pH}$ meter and moisture content (\%), acidity was calculated by formula and T.S.S. was checked by using hand refractometer.

\section{Moisture (\%)}

The sample was dried in drier at $65^{\circ} \mathrm{C}$ and initial and final weight was recorded by weighing balance. 

Final value - initial value
$(\%)$ moisture $=$

$$
\text { Initial value }
$$

\section{Acidity (\%)}

Ten grams of homogenized sample was taken and made up to $100-\mathrm{ml}$. volume in a volumetric flask. The contents were than filtered through Whatman No.1 filter paper; an aliquot of $1 \mathrm{ml}$. was taken for titration against $0.1 \mathrm{~N} \mathrm{NaOH}$ using phenolphthalein indicator and light pink colour as end point, to estimate titrable acidity in terms of tartaric acid (AOAC, 1995).

\section{Total soluble solids ( $\left.{ }^{0} \mathrm{Brix}\right)$}

The percentage of total soluble solids was determined using ERMA hand refractometer by placing a drop of the filtered juice on the refractometer prism. Before taking the reading, the refractometer was tested for error with distilled water (Ranganna, 1986).

\section{Sensory evaluation}

It was done using the 9 points hedonic score as given by Ranganna (2000).

\section{Flow Chart for Preparation of Aliv Fruit Jam}

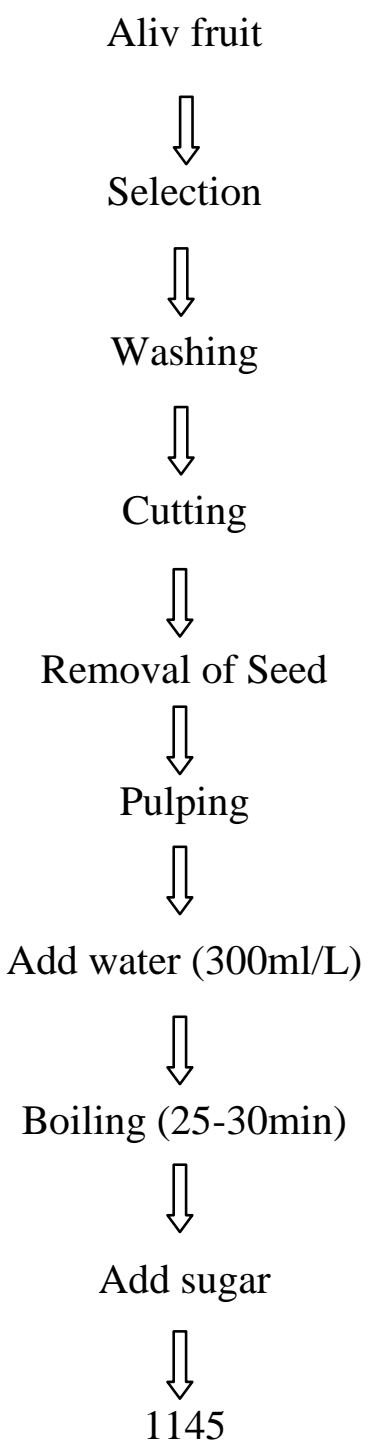


Add preservative (citric acid $0.5 \%$ )

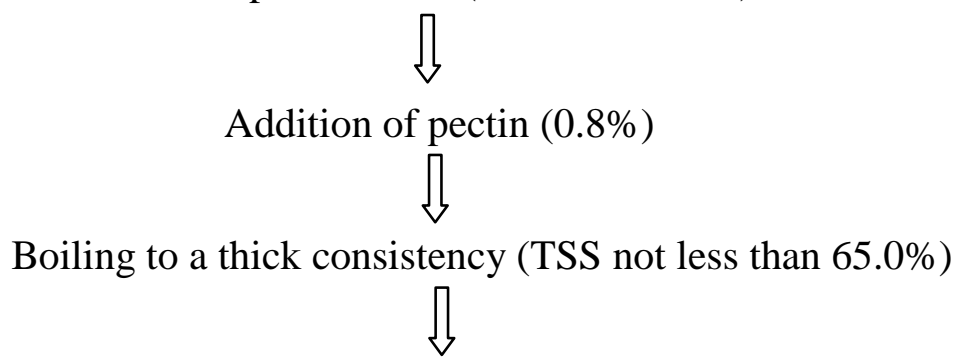

Sterilization of glass jar

Hot filling in glass jar

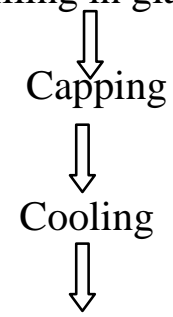

Waxing

Storage at ambient temperature

$\sqrt{ }$

Quality Analysis

$\sqrt{b}$

Sensory Analysis

\section{Results and Discussion}

\section{Sensory analysis}

The aliv were blended in the three sample of Aliv jam was made by blended of ingredients in different proportion see in table 1. The experiment was replicated 3 times and total 3 samples of jam were prepared and served to semi trained and trained panellists to judge the attributes. The samples were scored for their attributes such as colour, flavour, taste, appearance and overall acceptability and their mean was calculated and is given in table 1 . The overall acceptability of sample $S_{3}$ was better than rest of the samples (sample- $S_{1}, S_{2}$ ) due to cost of production for this sample ' $\mathrm{S}_{1}$ ' is very low and overall acceptance of this sample is better or slightly similar to the sample ' $\mathrm{S}_{2}$ '. Hence we discussed and concluded that the product is available to the consumer in affordable price and the production cost for making this highly nutritious product is low. Since the product satisfy the wants of both i.e. producer and consumer. Therefore we select the sample ' $\mathrm{S}_{3}$ ' for the large quantity production (Fig. 1).

\section{Preparation of jam from aliv blend}

The jam was prepared from the blend of aliv pulp as per Fruit Product Order, 1955 
specifications. That is TSS 65 Brix, acidity $0.46 \%$ and $\mathrm{pH} 3.1$ to 3.7 . The pulps were blended in different ratios as described in table 2 .

With the help of 10 panellist samples was evaluated and sample S3 was found most acceptable by panellist. Best blended jam was selected by the organoleptic evaluation which was conducted on 9 point hedonic scale for colour, appearance, taste, flavour and overall acceptability by 10 semi trained panellist or judges having prior experience of sensory evolution of fruits and vegetable product.

\section{Chemical analysis of Aliv fruit}

The data obtained on chemical properties such as acidity, moisture content, fat, ash, protein, carbohydrate and minerals for sample were recorded after the preparation on $0^{\text {th }}$ day and final value were as taken as given in table 3 .

\section{Chemical analysis of jam}

The data obtained on chemical properties such as acidity, moisture content, fat, ash, protein and carbohydrate for sample 3 were recorded after the preparation on $0^{\text {th }}$ day and final value were as taken as given in table 4 .

Table.1 Sensory parameters (marks according to 9 point Hedonic scale) of Aliv jam

\begin{tabular}{|l|c|c|c|}
\hline $\begin{array}{l}\text { Sensory quality attributes } \\
\text { and aliv jam samples }\end{array}$ & \multicolumn{3}{|c|}{ Sensory scale factors on 9- point scale } \\
\hline Fair & \multicolumn{2}{|c|}{ Medium } & Good \\
\hline Appearance & \multicolumn{3}{|l|}{} \\
\hline Sample 1 & 6.39 & 6.61 & 6.80 \\
\hline Sample 2 & 6.43 & 6.82 & 7.00 \\
\hline Sample 3 & 7.31 & 7.56 & 8.10 \\
\hline Color & \multicolumn{3}{|l}{} \\
\hline Sample 1 & 5.11 & 6.26 & 6.60 \\
\hline Sample 2 & 5.72 & 6.96 & 7.00 \\
\hline Sample 3 & 6.46 & 7.06 & 7.22 \\
\hline Texture & & & \\
\hline Sample 1 & 5.22 & 5.34 & 6.60 \\
\hline Sample 2 & 5.70 & 7.00 & 7.02 \\
\hline Sample 3 & 6.10 & 7.36 & 8.00 \\
\hline Taste & & & \\
\hline Sample 1 & 5.31 & 5.50 & 6.00 \\
\hline Sample 2 & 5.21 & 6.46 & 6.83 \\
\hline Sample 3 & 7.02 & 7.33 & 8.20 \\
\hline Overall acceptability & & & \\
\hline Sample 1 & 5.11 & 5.76 & 6.08 \\
\hline Sample 2 & 5.31 & 6.56 & 7.14 \\
\hline Sample 3 & 7.11 & 7.42 & 8.02 \\
\hline
\end{tabular}


Table.2 Variation of jam samples

\begin{tabular}{|l|l|l|l|l|}
\hline Ingredients & $\begin{array}{l}\text { Control } \\
(\mathbf{g})\end{array}$ & S1 (g) & S2 (g) & S3 (g) \\
\hline Fruit pulp & 60 & 55 & 50 & 45 \\
\hline Sugar & 35 & 40 & 45 & 50 \\
\hline Citric acid & 0.5 & 2 & 2 & 2 \\
\hline Pectin & $\mathbf{0 . 8}$ & $\mathbf{1}$ & $\mathbf{1}$ & $\mathbf{1}$ \\
\hline
\end{tabular}

Table.3 Nutritional composition of Aliv fruit

\begin{tabular}{|r|l|l|}
\hline Sr. No. & Parameters & Quantity/100gm \\
\hline $\mathbf{1}$ & Moisture & $74 \%$ \\
\hline $\mathbf{2}$ & Fat & $<0.1 \mathrm{~g}$ \\
\hline $\mathbf{3}$ & Ash & $0.38 \mathrm{~g}$ \\
\hline $\mathbf{4}$ & Protein & $0.48 \mathrm{~g}$ \\
\hline $\mathbf{5}$ & Carbohydrate & $25.1 \mathrm{~g}$ \\
\hline $\mathbf{6}$ & Acidity & $0.3 \%$ \\
\hline
\end{tabular}

Table.4 Nutritional value of aliv jam

\begin{tabular}{|c|c|c|}
\hline Sr. No. & Parameters & Quantity / 100gm \\
\hline 1 & Moisture & $20.5 \%$ \\
\hline 2 & Fat & $<0.1 \mathrm{~g}$ \\
\hline 3 & Ash & $0.62 \mathrm{~g}$ \\
\hline 4 & Protein & $0.39 \mathrm{~g}$ \\
\hline 5 & Carbohydrate & $78.1 \mathrm{~g}$ \\
\hline 6 & Acidity & $0.46 \%$ \\
\hline
\end{tabular}

Table.5 Effect on pH, acidity, moisture and TSS of jam during storage

\begin{tabular}{|l|l|l|l|l|l|}
\hline Parameter & 0day & $\mathbf{3 0}^{\text {th }}$ day & $\mathbf{6 0}^{\text {th }}$ day & $\mathbf{9 0}^{\text {th }}$ day & Mean \\
\hline pH & 3.1 & 3.3 & 3.4 & 3.7 & 3.37 \\
\hline Acidity & 0.46 & 0.49 & 0.49 & 0.51 & 0.48 \\
\hline Moisture & 20.5 & 20.5 & 20.9 & 20.1 & 20.5 \\
\hline TSS & 66 & 66 & 65.5 & 65.5 & 65.75 \\
\hline
\end{tabular}


Fig.1 Sensory analysis of jam

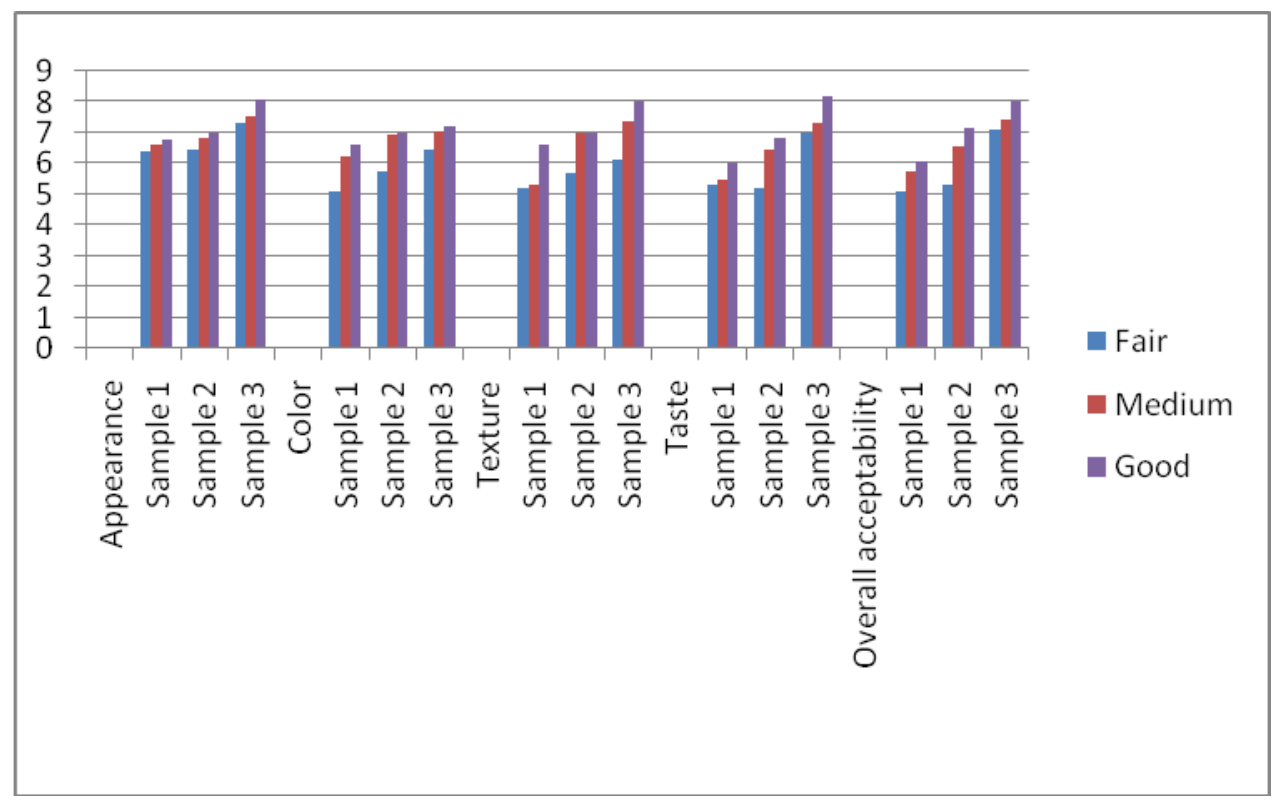

Fig.2 Physicochemical analysis of jam

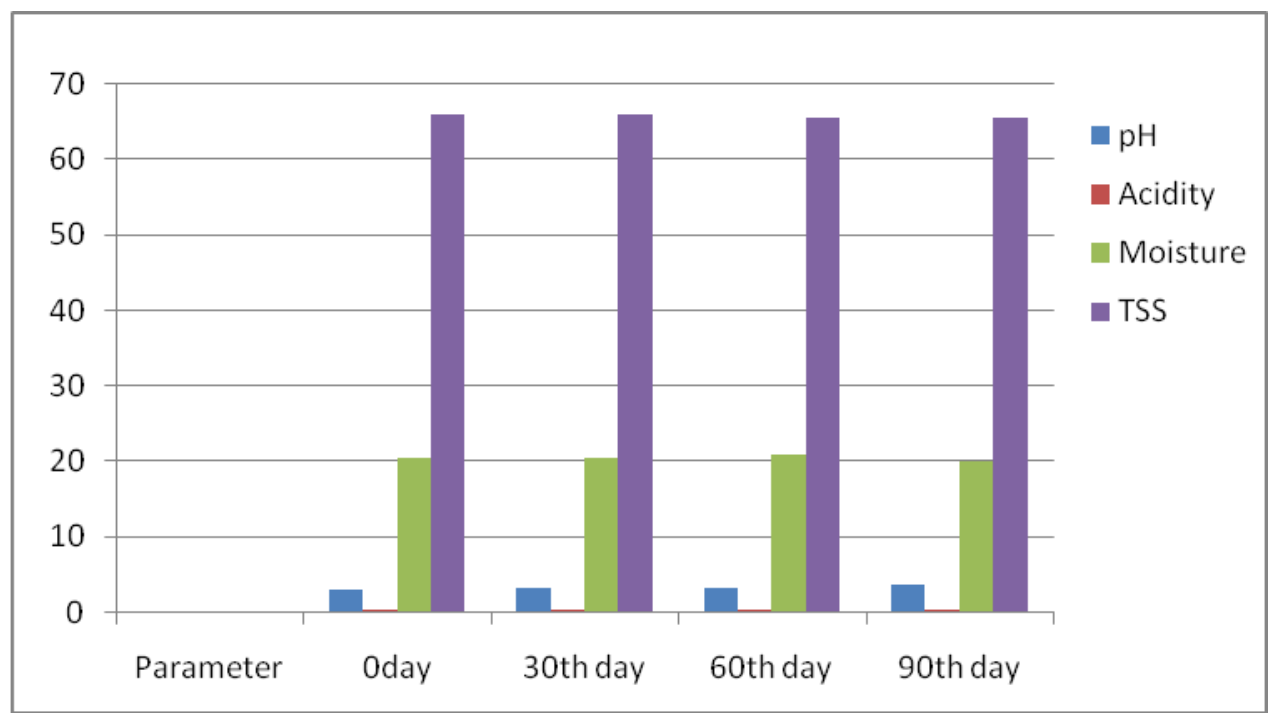

\section{Physicochemical analysis}

Physicochemical parameters involves in present study was-

$\mathrm{pH}$

Moisture

Acidity

T.S.S.
The physicochemical attributes includes $\mathrm{pH}$, moisture, acidity and T.S.S. content of processed and preserved processed foods was checked at gap of 0 day, 30, 60 and 90 days by $\mathrm{pH}$ meter, dry oven, titration and hand refractometer respectively (Fig. 2). Food products are being effectively preserved at low $\mathrm{pH}$. The $\mathrm{pH}$ estimation was done in order 
to find out whether a low $\mathrm{pH}$ was maintained throughout the study which could be an effective preservation. There was change in the $\mathrm{pH}$ during the entire storage (Table 5).

In conclusion, the formulation and standardization of recipe for aliv jam was carried out successfully. The health benefits of aliv jam are well known so the products are having some enrichment than the other marketed products.

The economic feasibility can be found Rs. $180 / \mathrm{kg}$ that is more cheaper than marketed jam (Kissan, Mapro, Tops, Malas) so the product can be satisfy the consumer in aspects as quality, cost and health. The aliv fruit has immense potential in multipurpose use. i.e. medicinal and economic. The aliv fruit also play a vital role in the economy of some tribal and rural landless people basically Konkan region.

\section{Recommendations}

This product could anybody used by children, adult, and old people but also by patient with diabetes, cancer, neurodegenerative, cardiovascular, aging, gastrointestinal and arthritis.

The aliv jam are cheap in cost and can be used daily to overcome deficiency of nutrients.

These nachos are not only for children but also for all age group.

\section{References}

A.O.A.C (1995).Official method of analysis $15^{\text {th }}$ edition, Association of Official Analytical Chemist Washington D.C.

Agrahar, M.D. and Subbulakshmi, G. (2005).Nutritive values of wild edible fruits, berries, nuts, roots and spices consumed by the khasi tribes of India, Ecology of Food and Nutrition, 44: 207223.
Bag, G.C. Devi, P.G. and Bhaigyabati, TH. (2016). Phytochemical Screening and antioxidant activity of Meyna laxiflora species found in imphal west district of Manipur, International Journal of Pharmaceutical Sciences Review and Research, 36(1): 137-143.

Biplab, DE. (2010). In vitro antioxidant activity of Meynalaxiflora seeds, International Journal of Chemical and Pharmaceutical Sciences, 1 (1).

Chothe, A. Patil, S. and Kulkarni, D.K. (2014). Unconventional wild fruits and processing in tribal area of Jawhar, Thane District, Bioscience Discovery, 5(1):19-23.

Chacko, C.M. and Estherlydia, D. (2014). Antimicrobial evaluation of jams made from indigenous fruit peels, International Journal of Advanced Research, 2:202-207.

CODEX, (2009).

Deshmukh, B.S. and Waghmode, A. (2011). Role of wild edible fruits as a food resource: traditional knowledge, International Journal of Pharmacy \& Life Sciences, 2:919-924.

Deshmukh, B. S. and Shinde, V. (2010). Fruits in the wilderness: a potential of local food resource, International Journal of Pharma and Bio Sciences, 1(2):1-5.

FSSAI (2006). Food safety and standards authority of India, Food Safety and Standards Act.

FPO (1955).Food safety and standards authority of India, Fruit Product Order Act.

Ganesh, T. Sen, S. Chakraborty, R. SV, S.K. HG, R. Sevukarajan, M. Majumder, J. and

Biplab, DE. (2010). In vitro antioxidant activity of Meynalaxiflora seeds, International Journal of Chemical and Pharmaceutical Sciences, 1 (1).

Guine, R.P.F. Figueiredo, A.R.B. Correia, P.M.R. and Goncalves, F.J. (2015). Chemical and sensorial evaluation of a newly developed bean jam, International Journal of Biological, Food, Veterinary and Agricultural Engineering, 9(4).

Ghate, VS. Kulkarni, D K. and Upadhye, AS. (1997). Karvanda (Carissa L.): An underutilized minor fruit of India, Plant 
Genetic Resources Newsletter, 109: 20-21.

Gayake, D.N. and Sharma, P.P. (2015). Traditional knowledge in treating different skin diseases from Ahmednagar district, Maharashtra, India, European Journal of Biomedical and Pharmaceutical sciences,2(1):190-195.

Hafeez, J. Raheem, I.UR. Aslam, H.K.W. Shakeel, A. and Sakandar, H.A. (2014). Comparative study of pectin extracted from wastes of guava and grapefruit and its application in strawberry jam, Global Advanced Research Journal of Food Science and Technology, 3(6):161-169

Hangarge, L. M. Kulkarni, D.K. Gaikwad, V.B. Mahajan, D.M. and Gunale, V.R. (2016). Plant diversity of sacred groves and its comparative account with surrounding denuded hills from Bhor region of Western Ghats, Bioscience Discovery, 7(2):121-127.

Haripyaree, A. and Guneshwor, K. (2012). Total antioxidant capacity of twenty wild and cultivated fruits, International Journal of Agriculture and Food Science, 2(4):146148.

Jena, S. (2013). Development of a preserved product from underutilized passion fruit and evaluation of consumer acceptance, Journal of Food Research and Technology, 1:11-20.

Khaple, A.K. Gurav, M. and Hubballi, S. (2012). Population studies of wild edible fruit tree species in kodagu, International Journal of Life Sciences, 1(3):48-55.

Kauthale, V. Kulkarni, D.Chavan, L. Patil, S. and Nalawade, A. (2017). Diversity of wild edible plants in dhadgaon block of Nandurbar district in

Maharashtra, India, International Journal of Current Research in Biosciences and Plant, 4(6):62-73.

Kopjar, M. Pilizota,V. Tiban, N.N. Subaric, D. Babic, J. Ackar, D.and sajdl, M. (2009). Strawberry jams: influence of different pectins on colour and textural properties, Czech Journal Food Science 27(1):20-28.

Kansci, G. Koubala, B.B. and Lape, I.M. (2003). Effect of ripening on the composition and the suitability for jam processing of different varieties of mango (Mangifera indica), African Journal of Biotechnology, 2(9):301-306.

Khan, S.H.Litaf, U. Shah, A.S. Bilal, M. Khan, A. Ali, M.U. Rani, S. Shah, and F,N. Naz. R. (2015). Comparative studies on the shelf stability of different types of apple jams, Pakistan Journal of Food Sciences, 25: 3742.

Kulkarni, DK. (2007). Germplasm collection of high value wild fruit species for global nutraceutical, Bharatiya Agro Industries Foundation, Development Research Foundation Pune, 42-46.

Lal, G. Siddappaa, G.S. and Tendon, G. L. (2015). Preservation of fruits and vegetables, $7^{\text {th }}$ reprint of second edition, Directorate of Knowledge Management in Agriculture, Indian Council of Agricultural Research, New Delhi, 156.

Ndabikunze, B. K. Masambu, B. N. Tiisekwa, B. P. M. and Issa-Zacharia, A. (2011). The production of jam from indigenous fruits using baobab (Adansonia digitata L.) powder as a substitute for commercial pectin, African Journal of Food Science, 5(3):168-175.

Nipunage, D.S. Sathe, K. Joshi, R. and Kulkarni, D.K. (2016). Natural heritage of biodiversity conservation in Palghar district, Maharashtra state, India, Indian Journal of Fundamental and Applied Life Science, 6(1):21-32.

Ozdogan, F. andY1lmaz, E. (2011). Evaluation of green tomato jams prepared from two kinds of tomatoes, AkademikGıda ${ }^{\circledR}$ / Academic Food Journal, 9(2):19-25.

Patil, M. M.Kalse, S.B. and Sawant, A.A. (2013); Preparation of guava jam blended with sapota, Agriculture Engineering International Commission of Agricultural and Biosystems Engineering Journal, 15(1): 167-172.

Patil, M.V. and Patil, D.A. (2001). Folk medicine of Nasik district (Maharashtra), India, Ancient Science of Life, 20:26-30.

Panda, S.P. Mohapatra, S.K. Jani, C. Sahu, A.K. Swain, K.K. and Biswal, M. (2014). Extended range of distribution of Meyna 
laxiflora Robyns (rubiaceae), International Journal of Innovative and Applied Research, 2(5): 6 - 9.

Quazi, A. and Molvi, I. (2015).A comprehensive review on Meyna laxiflora Robyns (Rubiaceae), International Journal of Pharmaceutical Sciences Review and Research, 35(2): 22-25.

Quazi, A. and Molvi, I. (2014). Ethnomedicinal survey of Meyna laxiflora in tribes of akkalkuwa, Nandurbar district, International Journal of Pharma and Bio Sciences, 5 (3): 225 - 230.

Quazi, M. A. and Molvi, K. I. (2014). Preliminary phytochemical evaluation of leaves of Meyna laxiflora, International Research Journal of Pharmacy, 5(9): 676678.

Rathod, V.S. andValvi, S.R. (2011). Antinutritional factors of some wild edible fruits from Kolhapur district, Recent Research in Science and Technology, 3(5): 68-72

Rahman, M. Markad, M.L. Kulkarni, T.S. and Meghdambar, P.V. (2014). Sensory attributes of the mixed fruit jam made from aloe vera, pineapple and mango, International Journal of Science and Research, 4(10).

Srivastava, R. P. and Kumar, S. (2002). Fruit and vegetable preservation principles and practices $3^{\text {rd }}$ edition, $C B S$ publishers and distributors pvt. Ltd, 215.

Singh, S.R. Phurailatpam, A.K. Wangchu, L. Ngangbam, P. and Chanu, T.M. (2014). Traditional medicinal knowledge of underutilized minor fruits as medicine in Manipur, International Journal of Agricultural Sciences, 4(8): 241-247.

Souad, A.M. Jamal, P. and Olorunnisola, K.S. (2012). Effective jam preparations from watermelon waste, International Food Research Journal, 19(4):1545-1549.

Singh, J. Singh, K. and Kaur, M. (2013).Division of post harvest technology, International Journal of Processing and Post Harvest Technology, 4:18 -25.

Shah, B.W. Khan, A.zeb, A. Khan, M.A. Shah, F.N. Amin, N.UL. Ayub, M. Wahab, S. Muhammad, A. and Khan, S.H. (2015). Quality evaluation and preparation of apple and olive fruit blended jam, Global Journal of Medical Research: L Nutrition \& Food Science, 15.

Shakir, I. Durrani, Y. Hussainm, I.Qazi, I.M. and Zeb, A. (2007). Physicochemical analysis of apple and pear mixed fruit jam prepared from varieties grown in azad Jammu and Kashir, International Journal of Food Safety, 9: 22-24.

Satheeskumar, R. and Murugesan, A.G. (2014). Application of electron beam irradiation for the preservation of mixed fruit jam and assessment of mineral content during storage, International Journal of Advanced Research in Biological Sciences, 1(4): 2227.

Vartak, VD. And Ghate, VS.(1994). AluMeynalaxi flora robyns a less known but promising wild fruit tree for tribal areas of western Maharashtra, Indian Journal Forestry, 3: 99-103.

\section{How to cite this article:}

Pravin N. Dhodade, Yogesh P. Dhaygude, Amit Kumar Tiwari and Vishal R. Birwatkar. 2019. Development of Jam from Under Exploited Fruit Aliv (Meyna laxiflora Robyns). Int.J.Curr.Microbiol.App.Sci. 8(03): 1143-1152. doi: https://doi.org/10.20546/ijcmas.2019.803.136 